\title{
Measuring the Impact of Rotavirus Acute Gastroenteritis Episodes (MIRAGE): A prospective community-based study
}

\author{
Martin Sénécal MSc${ }^{1}$, Marc Brisson $\mathrm{PhD}^{2,3}$, Marc H Lebel MD${ }^{4}$, John Yaremko MD ${ }^{5}$, Richard Wong MD ${ }^{6}$, \\ Lee Ann Gallant $M D^{6}$, Hartley A Garfield $M^{6}{ }^{6}$, Darryl J Ableman $M D^{7}$, Richard L Ward $\mathrm{PhD}^{8}$, \\ John S Sampalis $\mathrm{PhD}^{2,5,9}$, James A Mansi $\mathrm{PhD}^{1}$; for the MIRAGE study group
}

\begin{abstract}
M Sénécal, M Brisson, MH Lebel, et al; for the MIRAGE study group. Measuring the Impact of Rotavirus Acute Gastroenteritis Episodes (MIRAGE): A prospective community-based study. Can J Infect Dis Med Microbiol 2008;19(6):397-404.
\end{abstract}

BACKGROUND: Current assessments of the burden of rotavirus (RV)-related gastroenteritis are needed to evaluate the potential benefits of RV immunization interventions. The objective of the present study was to characterize the burden of RV gastroenteritis among children presenting in outpatient settings with gastroenteritis.

METHODS: Between January and June 2005, 395 children younger than three years of age presenting with gastroenteritis symptoms (at least three watery or looser-than-normal stools, or forceful vomiting within the previous $24 \mathrm{~h}$ period) were recruited from 59 Canadian clinics and followed for two weeks. Stool specimens were tested for the RV antigen. Gastroenteritis-related symptoms, health care utilization, parental work loss and other cases of gastroenteritis in the household were assessed by questionnaires and daily symptom cards that were completed by caregivers.

RESULTS: Of 336 conclusive test results, 55.4\% were RV positive $(\mathrm{RV}+)$. In addition to diarrhea, $67.2 \%$ and $89.3 \%$ of RV+ children experienced fever or vomiting, respectively. Compared with RVnegative (RV-) children, RV+ children were more likely to experience the three symptoms concurrently $(57.0 \%$ versus $26.7 \%$; $\mathrm{P}<0.001)$, to be hospitalized $(12.9 \%$ versus $3.9 \% ; \mathrm{P}=0.008)$ and to induce parental work loss $(53.8 \%$ versus $37.3 \%$; $\mathrm{P}=0.003)$. The median duration of gastroenteritis was eight days for RV+ children (nine days for RV- children). Additional cases of gastroenteritis were present in $46.8 \%$ of households in the RV+ group $(51.3 \%$ of households in the RV-group).

CONCLUSIONS: RV gastroenteritis cases were more severe than other gastroenteritis cases, were hospitalized more often and were associated with considerably more work loss.

\section{L'étude MIRAGE (pour Measuring the Impact of Rotavirus Acute Gastroenteritis Episodes) : Étude prospective basée dans la communauté}

HISTORIQUE : Il est important de procéder à des évaluations actuelles du fardeau de la gastro-entérite liée au rotavirus (RV) si nous voulons évaluer les avantages potentiels des interventions d'immunisation anti-RV. L'objectif de la présente étude était de caractériser le fardeau de la gastroentérite à RV chez des enfants non hospitalisés qui en sont atteints.

MÉTHODE : Entre janvier et juin 2005, 395 enfants de moins de trois ans vus pour des symptômes de gastro-entérite (au moins trois selles liquides ou plus molles que la normale ou vomissements violents au cours des 24 dernières heures) ont été recrutés dans 59 cliniques canadiennes et suivis pendant deux semaines. Les spécimens de selles ont été analysés pour recherche de l'antigène du RV. Les symptômes de gastro-entérite, l'utilisation des soins de santé, l'absentéisme des parents au travail et le déclenchement d'autres cas de gastro-entérite à la maison ont été évalués au moyen de questionnaires et de fiches quotidiennes de symptômes qui ont été complétées par les responsables des soins.

RÉSULTATS : Sur 336 tests concluants, 55,4\% étaient RV-positifs $(\mathrm{RV}+)$. En plus de la diarrhée, $67,2 \%$ et $89,3 \%$ des enfants RV+ présentaient respectivement de la fièvre ou des vomissements. Comparativement aux enfants RV-négatifs (RV-), les enfants RV+ étaient plus susceptibles de présenter concomitamment les trois symptômes, $57,0 \%$ contre $26,7 \%, \mathrm{p}<0,001$ ), d'être hospitalisés 12,9\% contre 3,9\% $(\mathrm{p}=0,008)$ et d'entraîner l'absentéisme des parents au travail $(53,8 \%$ contre $37,3 \%, p=0,003$ ). La durée médiane de la gastro-entérite a été de huit jours chez les enfants RV+ (neuf jours chez les enfants RV-). D'autres cas de gastro-entérite se sont manifestés dans $46,8 \%$ des foyers du groupe $\mathrm{RV}+(51,3 \%$ des foyers du groupe RV-).

CONCLUSION : Les cas de gastro-entérite à RV ont été plus graves que les autres cas de gastro-entérite, ont dû être hospitalisés plus souvent et ont été associés à beaucoup plus d'absentéisme au travail.

Key Words: Burden of illness; Gastroenteritis; Health care resource utilization; Rotavirus; Work loss

\footnotetext{
In both developed and developing countries, rotavirus (RV) remains a major cause of gastroenteritis among infants and young children (1). Severe dehydration that may lead to hospitalization is the most common consequence of RV gastroenteritis. In industrialized countries, RV gastroenteritis is the most frequent cause of hospitalization for dehydrating diarrhea and vomiting (2-9).

Recently, vaccines targeting the most common RV strains have been introduced, thus offering protection against RV gastroenteritis, with an anticipated impact on decreasing the associated burden of illness (3,10-17). Given that the burden of RV may not be consistent across different regions and over time, regional data that quantify the various aspects of the current burden of the disease are needed to facilitate the assessment of

${ }^{1}$ Merck Frosst Canada Ltd, Montreal; ${ }^{2}$ Université Laval, Laval; ${ }^{3}$ Unité de recherche en santé des populations, Centre hospitalier affilié universitaire de Québec, Quebec City; ${ }^{4}$ Centre hospitalier universitaire Sainte-Justine, Université de Montréal; ${ }^{5}$ McGill University Health Centre, Montreal, Quebec; ${ }^{6}$ The University of Toronto, Toronto, Ontario; ${ }^{7}$ The University of British Columbia, Vancouver, British Columbia; ${ }^{8}$ Cincinnati Children's Hospital Medical Center, Cincinnati, Ohio, USA; ${ }^{9} J S S$ Medical Research, Montreal, Quebec

Correspondence and reprints: Dr John S Sampalis, Department of Surgery, McGill University, 4492 St Catherine Street West, Westmount, Quebec H3Z 1R7. Telephone 514-934-6116 ext 232, fax 514-934-9913, e-mail jsampalis@jssresearch.com

Received for publication January 7, 2008. Accepted June 4, 2008
} 


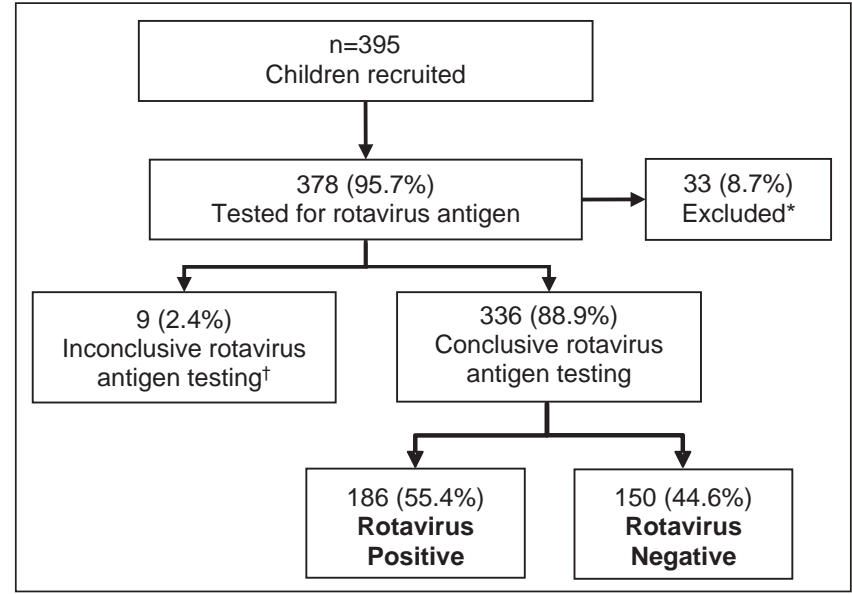

Figure 1) Study flow chart. *Patients for whom gastroenteritis symptoms began more than seven days before baseline physician visit; Indeterminate result by ELISA testing

the potential benefit of immunization programs. In addition to providing valuable regional information, local studies will contribute to the data that will allow the assessment of the global RV gastroenteritis-related burden of illness, and will allow for the identification of between-region variations with respect to the epidemiology and burden of RV $(3,15,18,19)$.

The current data in the literature have confirmed that RV gastroenteritis burden is significant in the United States (20-22), Europe $(3,15,23-32)$ and Asia (33-42). With respect to Canada, there have been a number of published studies (43-45) that have described the epidemiology of RV gastroenteritis, but none have been conducted recently. Furthermore, Canadian studies $(43,45)$ have mainly described RV gastroenteritis using data from hospitalized children, which limits both the understanding of the clinical presentation of RV gastroenteritis and its related burden of illness at the community level. At this point in time, considering the availability of RV vaccines, there is a need for recent data describing the societal impact of RV gastroenteritis.

The aim of the present prospective, community-based study was to characterize the burden of RV gastroenteritis episodes in infants and young children seeking health care for gastroenteritis in Canada. More specifically, the study describes symptoms, health care utilization, parental work loss and additional household gastroenteritis among children presenting with RV gastroenteritis in Canadian outpatient settings. A secondary objective of the study was to compare these aspects between RVpositive $(R V+)$ and $R V$-negative $(R V-)$ children experiencing gastroenteritis.

\section{Study design}

\section{PATIENTS AND METHODS}

The present study was a prospective, multicentre, observational study of children younger than three years of age presenting with gastroenteritis. Cohort inception took place between January 1 and June 31, 2005 - the expected epidemic RV season in Canada. Inclusion in the cohort took place at the time of presentation with gastroenteritis at the participating sites. Follow-up was for two weeks. Patients were enrolled from 59 practices across Canada, of which 28 (47\%) were family physician and 31 (53\%) were pediatrician practices. The majority of the sites $(78.0 \%)$ were based in the provinces of Ontario $(n=34)$ and Quebec $(n=12)$. The other sites were based in the following provinces
- British Columbia $(n=7)$, Manitoba $(n=3)$, Saskatchewan $(n=2)$ and Nova Scotia $(n=1)$. Given that enrolment took place during the course of routine clinical practices, it was not feasible to ensure systematic recruitment of all eligible patients or to record all instances of eligible patients whose caregivers declined invitation to take part in the study. Therefore, the proportion of eligible patients who were included in the study sample was not documented.

The protocol and the informed consent sheet were approved by the Canadian SHIELD Ethics Review Board and the College of Physicians \& Surgeons of Alberta.

\section{Inclusion and exclusion criteria}

To be eligible for inclusion in the study, patients had to be younger than three years of age at the time of presentation to the physicians' offices with gastroenteritis, and informed consent had to be provided by the parents or legal guardians. Inclusion criteria were defined as the presence of at least three watery or looserthan-normal stools, or forceful vomiting within the previous $24 \mathrm{~h}$ period. Patients were eligible irrespective of their gastroenteritis history, unless they had a gastroenteritis episode that required hospitalization. In addition, children for whom current gastroenteritis symptom onset was more than seven days before enrolment were excluded from the analysis. Patients were excluded if they had received treatment with antibiotics or immunoglobulins within 30 days before study entry. If the patient or the patient's mother was positive for HIV, hepatitis B or C, or had participated in an RV immunization program, he or she was also excluded from the study.

\section{Data collection}

At recruitment, the physician completed the case report form, which included questions about the patient (eg, age, sex, height and weight), and current and past symptoms attributable to the gastroenteritis episode. Caregivers completed a selfadministered questionnaire regarding the socioeconomic setting, demographic profile, breastfeeding history and household characteristics, including the age of household members.

Within one week of recruitment, patient stool samples were obtained, refrigerated and shipped on dry ice to the Cincinnati Children's Hospital Medical Center (Ohio, USA). RV testing was conducted using ELISA developed at the James $\mathrm{N}$ Gamble Institute of Medical Research (Ohio, USA) $(46,47)$. This test is a multistep procedure that uses a negative capture antibody control to eliminate false-positive reactions and biotin-avidin additions to increase the sensitivity of the assay. To be considered $\mathrm{RV}+$, wells had to have an optic density of at least 0.31 and a positive to negative optic density ratio of least 1.63. When the background was too high to be conclusive, specimens were diluted up to $1: 50$. If the values remained indeterminate, the results were reported as inconclusive. No information with respect to other etiological agents that may cause gastroenteritis was documented.

On days 1, 7 and 14 postrecruitment, caregivers completed a self-administered questionnaire that included questions regarding gastroenteritis-related emergency room (ER) visits and hospitalizations. The questionnaire also ascertained the work days lost by the father or the mother because of their child's (ie, the study patient) gastroenteritis episode. To document potential cases of RV transmissions between family members, caregivers were also asked whether there had been other cases of gastroenteritis in the household over a four-week period (from two weeks before to two weeks after enrolment of the study patient). Whether the 
TABLE 1

Characteristics of children younger than three years of age presenting to physicians' offices with gastroenteritis*

\begin{tabular}{|c|c|c|c|}
\hline Characteristic & $\begin{array}{l}\text { Rotavirus } \\
\text { positive } \\
(n=186)\end{array}$ & $\begin{array}{c}\text { Rotavirus } \\
\text { negative } \\
(n=150)\end{array}$ & $\mathbf{P}^{\dagger}$ \\
\hline \multicolumn{4}{|l|}{ Age distribution in months } \\
\hline$<6$ & $10(5.4)$ & $26(17.3)$ & 0.013 \\
\hline $6-11$ & $52(28.0)$ & $37(24.7)$ & \\
\hline $12-17$ & $53(28.5)$ & $29(19.3)$ & \\
\hline $18-23$ & $33(17.7)$ & $26(17.3)$ & \\
\hline $24-29$ & $17(9.1)$ & $16(10.7)$ & \\
\hline $30-35$ & $21(11.3)$ & $16(10.7)$ & \\
\hline Sex, male & $109(58.6)$ & $79(52.7)$ & 0.276 \\
\hline Child care centre attendance & $63(33.9)$ & $45(30.0)$ & 0.450 \\
\hline Ever been breastfed & $122(66.0)$ & $111(75.0)$ & 0.073 \\
\hline $\begin{array}{l}\text { At least one parent unemployed } \\
\text { or on parental leave }\end{array}$ & $98(55.4)$ & $83(59.3)$ & 0.484 \\
\hline \multicolumn{4}{|l|}{ Family income (\$) } \\
\hline$\leq 19,999$ & $10(5.4)$ & $8(5.3)$ & 0.942 \\
\hline $20,000-49,999$ & $39(21.0)$ & $37(24.7)$ & \\
\hline $50,000-69,999$ & $22(11.8)$ & $18(12.0)$ & \\
\hline$\geq 70,000$ & $80(43.0)$ & $62(41.3)$ & \\
\hline Decline to reply & $35(18.8)$ & $25(16.7)$ & \\
\hline
\end{tabular}

Data are $n(\%)$ of patients. ${ }^{*}$ Percentages reflect only patients for whom the information was available; ' ${ }^{\dagger}$ Statistical significance of the observed differences was determined using the $\chi^{2}$ test for distributions of categorical variables and the Student's test for means of continuous variables

other gastroenteritis episodes in the household began before or after the study patient's illness was not documented.

During the two-week follow-up, caregivers also completed daily symptom diary cards that recorded the presence and duration of diarrhea, vomiting and fever. Confirmed presence of diarrhea was defined as at least two watery or looser-than-normal stools per day; presence of fever was defined as a body temperature higher than $38^{\circ} \mathrm{C}$ at any time. During the two-week study follow-up period, caregivers were not aware of the RV results.

\section{Statistical analysis}

For each day of the study observation period (beginning from seven days before to 14 days after the baseline date), the proportion of patients with diarrhea, vomiting or fever, and with all three symptoms concurrently were described. The duration of each gastroenteritis episode was defined as the time elapsed from the onset of the first symptom (diarrhea, vomiting or fever) until all symptoms were resolved. An episode of diarrhea, vomiting or fever was assumed to be resolved when the specific symptom was absent for three consecutive days. In the data analysis, only the first incidence of each symptom was included; the occurrence of subsequent symptom incidences was not included in the analysis. For example, if diarrhea was reported on days 1 to 3 and then again on days 12 to 13 , only the first incidence occurring from days 1 to 3 was included. The duration of a symptom episode was censored if it was still present at the end of follow-up or if an episode was reported at enrolment, but follow-up data for the episode were missing. When a symptom was not reported at enrolment and follow-up diary cards were not completed, the child was considered as not having experienced the symptom over the course of the disease.
TABLE 2

Symptoms experienced by children younger than three years of age who sought physician care because of gastroenteritis

\begin{tabular}{|c|c|c|c|}
\hline & $\begin{array}{l}\text { Rotavirus } \\
\text { positive } \\
(n=186)\end{array}$ & $\begin{array}{c}\text { Rotavirus } \\
\text { negative } \\
(n=150)\end{array}$ & $\mathbf{P}^{*}$ \\
\hline $\begin{array}{l}\text { Number of days between onset of } \\
\text { the first symptom and baseline } \\
\text { physician visit, mean } \pm \text { SD }\end{array}$ & $2.9 \pm 1.7$ & $3.0 \pm 1.8$ & 0.397 \\
\hline \multicolumn{4}{|l|}{$\begin{array}{l}\text { Symptoms experienced over the } \\
\text { course of the disease, } n(\%)\end{array}$} \\
\hline Diarrhea & $186(100.0)$ & $146(97.3)$ & 0.025 \\
\hline Vomiting & $166(89.3)$ & $99(66.0)$ & $<0.001$ \\
\hline Fever & $125(67.2)$ & $80(53.3)$ & 0.010 \\
\hline \multicolumn{4}{|l|}{$\begin{array}{l}\text { Symptom episodes beginning after } \\
\text { baseline physician visit }{ }^{\dagger}, \mathrm{n}(\%)\end{array}$} \\
\hline Diarrhea & $0(0.0)$ & $3(2.1)$ & 0.050 \\
\hline Vomiting ( $n=166)$ & $6(3.6)$ & $21(21.2)$ & $<0.001$ \\
\hline Fever $(n=125)$ & $32(25.6)$ & $39(48.8)$ & $<0.001$ \\
\hline \multicolumn{4}{|l|}{ Combination of symptoms, $\mathrm{n}(\%)$} \\
\hline Single symptom & $10(5.4)$ & $33(22.0)$ & $<0.001$ \\
\hline Diarrhea and fever, but no vomiting & $10(5.4)$ & $22(14.7)$ & \\
\hline Diarrhea and vomiting, but no fever & $51(27.4)$ & $37(24.7)$ & \\
\hline Diarrhea, vomiting and fever & $115(61.8)$ & $58(38.7)$ & \\
\hline \multicolumn{4}{|l|}{$\begin{array}{l}\text { Intensity of symptoms reported at } \\
\text { baseline physician visit }{ }^{\ddagger}, \text { mean } \pm S D\end{array}$} \\
\hline Daily frequency of diarrhea $§$ & $5.4 \pm 3.5$ & $5.1 \pm 2.5$ & 0.254 \\
\hline Daily frequency of vomiting & $4.3 \pm 3.0$ & $2.8 \pm 2.1$ & $<0.001$ \\
\hline Highest recorded temperature $\left({ }^{\circ} \mathrm{C}\right)$ & $39.3 \pm 0.8$ & $39.0 \pm 0.8$ & 0.144 \\
\hline \multicolumn{4}{|l|}{$\begin{array}{l}\text { Duration of episodes, days, } \\
\text { median }(25 \text { th-75th percentile })^{\pi}\end{array}$} \\
\hline Diarrhea & $7(5-10)$ & $8(6-12)$ & 0.010 \\
\hline Vomiting & $4(3-6)$ & $4(2-6)$ & 0.532 \\
\hline Fever & $4(2-5)$ & $4(2-6)$ & 0.877 \\
\hline Gastroenteritis episode & $8(6-10)$ & $9(7-13)$ & $<0.001$ \\
\hline
\end{tabular}

Duration with three concurrent

symptoms, \%

$\begin{array}{lrrr}\geq 1 \text { day } & 57.0 & 26.7 & <0.001 \\ \geq 2 \text { days } & 45.8 & 14.7 & \\ \geq 4 \text { days } & 23.7 & 3.2 & \end{array}$

*Statistical significance of the observed differences was determined using the $\chi^{2}$ test for distributions of categorical variables, the Student's t test for means of continuous variables and the log-rank test for durations; tThe percentage is based on the number of children having experienced the symptom ${ }^{\ddagger}$ Represents episodes which began before baseline physician visit; \$Number of watery or looser-than-normal stools; TPProduct-limit estimates

Work loss related to the gastroenteritis episode was described as the proportion of patients whose parents required time off from work. Similarly, the presence of other gastroenteritis episodes in family members was described as the proportion of patients whose household members experienced gastroenteritis during the two-week period before or the two-week period after the baseline visit, as well as the proportion of household members having experienced gastroenteritis during the four-week time window.

Gastroenteritis-related parameters were compared between $\mathrm{RV}+$ and RV- groups. Student's $t$ tests and $\chi^{2}$ tests were used to assess the statistical significance of differences between means of 


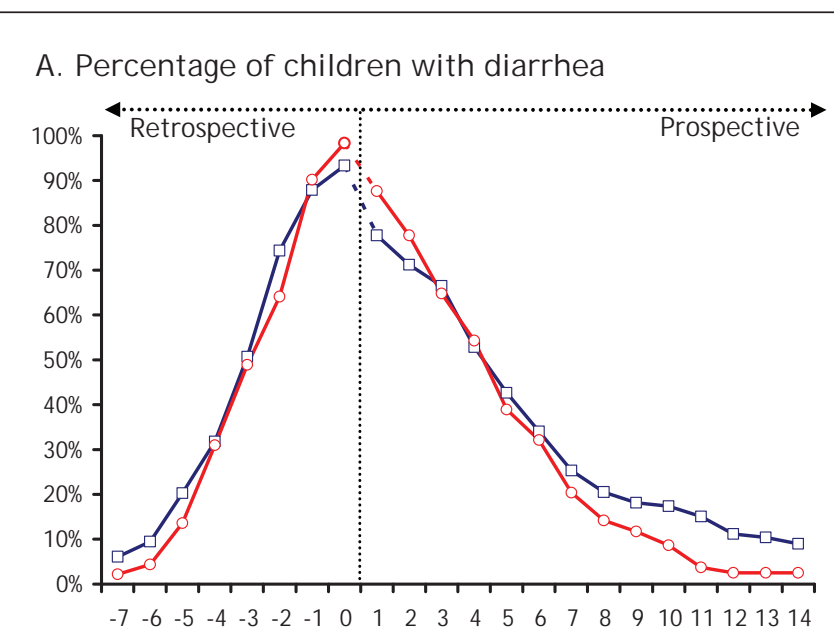

Days from baseline physician visit (enrolment)

\section{B. Percentage of children with vomiting}

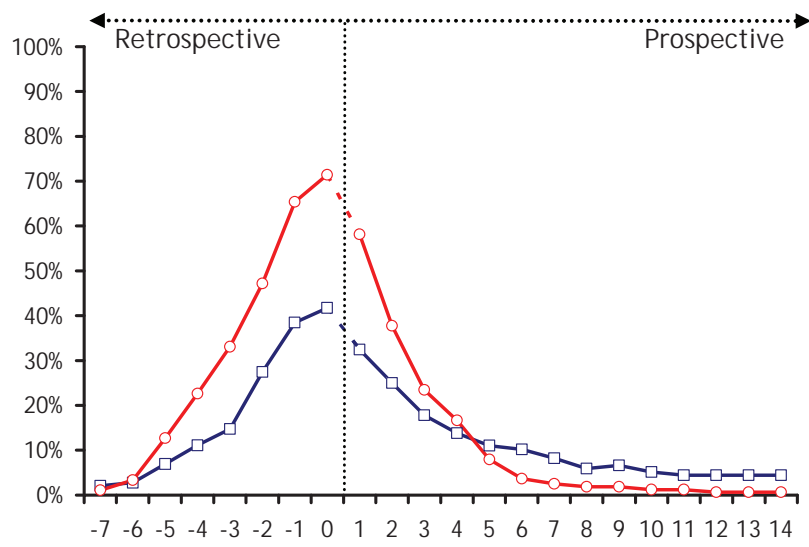

Days from baseline physician visit (enrolment)

\section{$-\square-$ Rotavirus negative $-\mathrm{O}-$ Rotavirus positive}

\section{Percentage of children with fever}

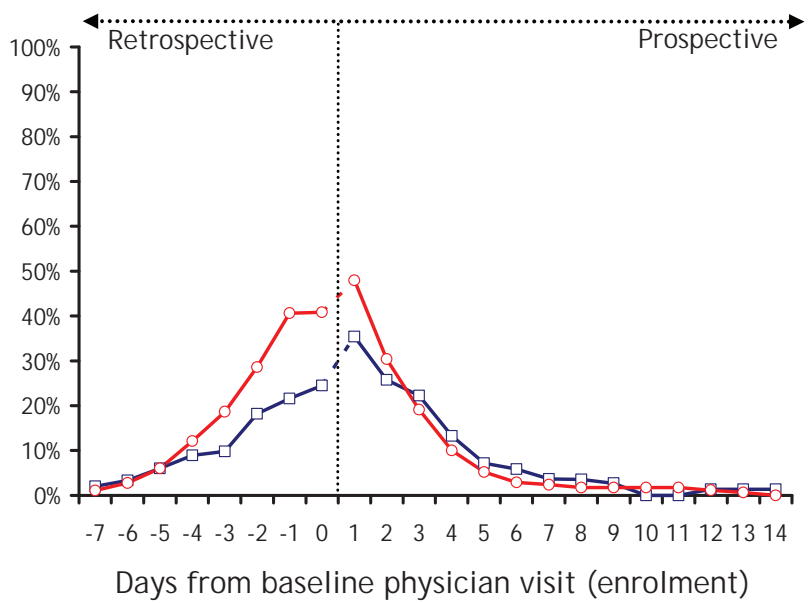

\section{Percentage of children with three concurrent symptoms}

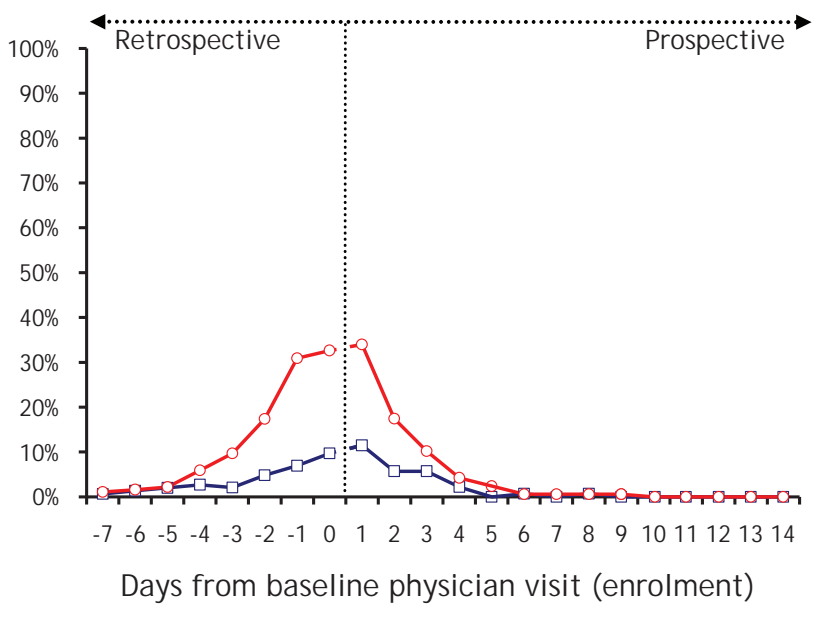

Figure 2) Presence of gastroenteritis symptoms over time - period going from seven days before baseline physician visit to 14 days after baseline physician visit (enrolment). At enrolment (day 0), the presence of symptoms for day -7 to day 0 was documented retrospectively by asking simple questions of caregivers about the presence and the onset of gastroenteritis symptoms. For day 1 to day 14 , the daily presence of symptoms was documented prospectively through symptoms diary cards completed by caregivers

continuous variables and distributions of categorical variables, respectively. For each age group, the proportion of household members who experienced gastroenteritis was compared between the RV+ and RV- groups using logistic regression models with generalized estimating equations, which take into account the correlation between members of the same household. The duration of symptoms was analyzed using the Kaplan-Meier estimation method, and the statistical significance of differences between RV+ and RV- gastroenteritis cases with respect to the duration of symptoms was assessed using log-rank tests.

\section{Study population}

\section{RESULTS}

A total of 395 children were recruited, 378 (95.7\%) of whom had their stools tested for RV antigen. There were 33 (8.7\%) (14 RV+; 19 RV-) patients who were excluded from the analysis due to symptom onset of more than seven days before enrolment. Nine $(2.4 \%)$ additional children were excluded due to inconclusive RV test results. Of the remaining 336 children, 186 (55.4\%) were RV+ and 150 (44.6\%) were RV- (Figure 1). The two symptom diary cards were returned for $285(84.8 \%)$ patients $(86.0 \%$ $\mathrm{RV}+$ and $83.3 \% \mathrm{RV}-$ ).

Description of study sample

The age distribution of children with RV + and RV- gastroenteritis differed significantly $(\mathrm{P}=0.013)$, with the proportion of patients younger than six months of age in the RV- group being higher than the proportion of patients in the RV+ group (Table 1). Although not statistically significant, a higher proportion of RV- children had been breastfed compared with the RV+ group. Other baseline characteristics, including sex, child care, parents' employment status and family income were similar between RV+ and RV-patients (Table 1). 


\section{Gastroenteritis symptoms}

Table 2 describes the presence and duration of gastroenteritis symptoms during the study period. Patients were enrolled in the study for an average of three days after the onset of the first gastroenteritis symptom. During the entire course of the disease, diarrhea was observed in all RV+ children, while vomiting and fever were observed in $89.3 \%$ and $67.2 \%$, respectively. All three symptoms were experienced by $61.8 \%$ of RV+ children and the majority $(57.0 \%)$ of those experienced the three symptoms concurrently for at least one day. Compared with the RV- patients, those who were RV+ were more likely to experience multiple and concurrent gastroenteritis symptoms $(\mathrm{P}<0.001)$. In addition, among children who had experienced vomiting at presentation, those who were RV+ vomited more frequently compared with the RV- patients $(\mathrm{P}<0.001)$. Although the duration of vomiting and fever was similar for $\mathrm{RV}+$ and $\mathrm{RV}$ - children, diarrhea episodes were longer in duration for $\mathrm{RV}$ - children $(\mathrm{P}=0.010)$, resulting in a longer gastroenteritis episode compared with the RV+ group $(\mathrm{P}<0.001)$. However, the duration of all concurrent symptoms was higher for the RV+ patients $(\mathrm{P}<0.001)$.

Figure 2 describes the proportion of patients with each individual symptom (Figures 2A, 2B and 2C) and all three gastroenteritis symptoms (Figure 2D) during the time period between seven days before the baseline visit and 14 days after the baseline visit. The prevalence of diarrhea and vomiting peaked on the day of the baseline physician visit, while the prevalence of fever and presence of three concurrent symptoms peaked on the day following enrolment. Diarrhea episodes started at approximately the same time for both groups, but vomiting and fever occurred later in the RV- group. Among RV+ and RV- children respectively, vomiting episodes began 2.3 and 1.1 days before baseline physician visit $(\mathrm{P}<0.001)$ and fever episode onset occurred 1.4 days before and 0.2 day after enrolment $(\mathrm{P}=0.003)$.

\section{Health care resource utilization}

Table 3 summarizes the data regarding health care resource utilization in the study sample. RV+ patients were significantly more likely to be hospitalized than RV-patients (12.9\% versus $3.9 \% ; \mathrm{P}=0.008)$. Of the $\mathrm{RV}+$ patients, $16.4 \%$ visited the $\mathrm{ER}$ but were not hospitalized, of whom $11.1 \%$ were rehydrated intravenously. In the RV- group, $11.8 \%$ visited the ER without being admitted and none of these children required intravenous (IV) rehydration. Overall, compared with RV- children, RV+ children were more likely to visit an ER or to be hospitalized $(29.3 \%$ versus $15.7 \%, \mathrm{P}=0.008)$ and to be IV rehydrated (13.2\% versus $3.2 \%, \mathrm{P}=0.002$ ).

\section{Work loss due to gastroenteritis}

The data describing parental work loss related to the gastroenteritis episode of the study patients are reported in Table 3. Parents of RV+ patients were more likely to miss work due to the gastroenteritis episode than parents of RV- patients $(\mathrm{P}=0.003)$. Among RV+ children, $21.0 \%$ of parents who had taken time off work missed more than four days of work, compared with $14.3 \%$ of parents of $R V-$ patients $(\mathrm{P}=0.002)$.

Overall, the average number of parental work days lost per family was higher in the $\mathrm{RV}+$ group than the RV- group ( 1.5 days versus 0.9 day; $\mathrm{P}=0.003$ ). As expected, families in which both parents were working were more likely to have taken time off work than other families $(73.4 \%$ versus $40.8 \%$ in the $\mathrm{RV}+$ group, $\mathrm{P}<0.001 ; 61.4 \%$ versus $22.9 \%$ in the $\mathrm{RV}-$
TABLE 3

Health care utilization, work days lost and additional household gastroenteritis in patients with and without rotavirus infection*

\begin{tabular}{|c|c|c|c|}
\hline & $\begin{array}{c}\text { Rotavirus } \\
\text { positive } \\
(n=186)\end{array}$ & $\begin{array}{c}\text { Rotavirus } \\
\text { negative } \\
(n=150)\end{array}$ & $\mathbf{P}^{\dagger}$ \\
\hline \multicolumn{4}{|l|}{ Health care utilization $\ddagger$} \\
\hline Physician consultation only & $121(70.8)$ & $107(84.3)$ & 0.010 \\
\hline ER visit, but not hospitalizec & $28(16.4)$ & $15(11.8)$ & \\
\hline Hospitalization & $22(12.9)$ & $5(3.9)$ & \\
\hline Intravenous rehydration & $25(13.2)$ & $4(3.2)$ & \\
\hline \multicolumn{4}{|l|}{ Work loss } \\
\hline $\begin{array}{l}\text { Families having taken time } \\
\text { off work }\end{array}$ & $100(53.8)$ & $56(37.3)$ & 0.003 \\
\hline $\begin{array}{l}\text { Number of work days lost } \\
\text { per family (mean } \pm \text { SD) }\end{array}$ & $1.5 \pm 2.2$ & $0.9 \pm 1.7$ & 0.003 \\
\hline $\begin{array}{l}\text { Number of work days lost } \\
\text { per family having taken } \\
\text { time off work (mean } \pm S D\end{array}$ & $2.8 \pm 2.3$ & $2.3 \pm 2.0$ & 0.194 \\
\hline \multicolumn{4}{|l|}{ Distribution (days) } \\
\hline $0.5-2$ & $51(51.0)$ & $37(66.1)$ & 0.190 \\
\hline $2.5-4$ & $28(28.0)$ & $11(19.6)$ & \\
\hline$>4$ & $21(21.0)$ & $8(14.3)$ & \\
\hline \multicolumn{4}{|l|}{$\begin{array}{l}\text { Additional gastroenteritis in the } \\
\text { household } \$ \pi\end{array}$} \\
\hline $\begin{array}{l}\text { Families reporting other } \\
\text { gastroenteritis cases in } \\
\text { the household }\end{array}$ & $87(46.8)$ & $77(51.3)$ & 0.406 \\
\hline $\begin{array}{l}\text { Other household } \\
\text { members experiencing } \\
\text { gastroenteritis }\end{array}$ & $117 / 483(24.2)$ & $120 / 385(31.2)$ & 0.080 \\
\hline \multicolumn{4}{|l|}{ By age group (years) } \\
\hline$<2$ & $11 / 25(44.0)$ & $10 / 21(47.6)$ & 0.809 \\
\hline $2-5$ & $26 / 71(36.6)$ & $19 / 48(39.6)$ & 0.745 \\
\hline $6-18$ & $5 / 41(12.2)$ & $8 / 34(23.5)$ & 0.236 \\
\hline$>18$ & $75 / 346(21.7)$ & $83 / 282(29.4)$ & 0.061 \\
\hline
\end{tabular}

Data are $n(\%)$ of patients, unless otherwise indicated. ${ }^{*}$ Percentages reflect only patients for whom the information was available; 'Statistical significance of the observed differences was determined using the $\chi^{2}$ test for distributions of categorical variables, the Student's t test for means of continuous variables and the log-rank test for durations; $\ddagger_{n=171}$ for rotavirus-positive patients, and $n=127$ for rotavirus-negative patients; $§$ The proportions of other household members experiencing gastroenteritis were compared using a logistic regression model with generalized estimating equations to account for the correlation between members of the same household; TWithin two weeks before or after the index case's baseline physician visit. ER Emergency room

group, $\mathrm{P}<0.001)$. Work loss was also associated with the intensity of health care sought. Parents of RV + children who visited an ER without being admitted missed an average of two days of work compared with three days for parents whose children were hospitalized.

Additional gastroenteritis cases in the household

In approximately $50 \%$ of families, at least one other household member experienced gastroenteritis in the four-week time window from two weeks before to two weeks after the baseline visit of the index case (Table 3). When the data were stratified according to the ages of household members, similar patterns were observed for households of RV+ and RV- children. The highest proportion of gastroenteritis was observed among 
household members younger than two years of age, but this proportion remained high (greater than 12\%) in all age groups, including adults.

\section{DISCUSSION}

The present study was a prospective cohort study that described some aspects of the burden of RV gastroenteritis episodes in Canada by quantifying the prevalence, duration and severity of gastroenteritis symptoms as well as the impact on health care utilization and parental work loss.

RV was detected in $55.4 \%$ of children with gastroenteritis. This is higher than the proportions previously observed in Canada in the same age group (26\%) (43). The higher proportion of RV cases found in the present study may be due to yearly variations in RV incidence, differences in the RV study period or differences in the inclusion criteria. The study conducted by Ford-Jones et al (43) included the months of November and December, which were not covered in our study. RV gastroenteritis incidence is generally low during these two months, which partially explains why we observed a higher proportion of $\mathrm{RV}+$ cases. In addition, our inclusion criteria required three or more watery or looser-than-normal stools in the previous $24 \mathrm{~h}$, while that applied by Ford-Jones et al (43) allowed for a single watery stool during that same time frame. This may have led to the inclusion of less severe gastroenteritis cases, diluting the percentage of the more severe RV+ cases. Recently, an American study (21) with a similar time period of analysis and inclusion criteria reported more comparable RV+ rates between $31 \%$ and $50 \%$.

The data in the literature $(9,20,21,44)$ have shown that RV gastroenteritis generally occurs between six and 23 months of age. The age-specific distribution of RV gastroenteritis in our study is compatible with these results. The presence of diarrhea, vomiting, fever and dehydration in RV gastroenteritis has been well documented $(9,21,24,43,45)$. In the present study, we observed that the majority of RV+ patients experienced all three of these symptoms and that, for almost one-quarter of the RV gastroenteritis cases, the three symptoms were persistent for at least four days. The presence of multiple gastroenteritis symptoms for an extended period of time is a risk factor for dehydration. For these patients who also have frequent vomiting, oral rehydration is difficult. This would explain the observation that $13.2 \%$ of $\mathrm{RV}+$ patients required IV rehydration. In our study, more than one in four RV+ children visited the ER (26.9\%) and one in eight $(12.9 \%)$ were hospitalized. These results are comparable with a study conducted in the Greater Toronto Area (Ontario) (44), in which $24 \%$ of RV+ children seen by a doctor sought further care.

RV gastroenteritis is a common illness in young children and is generally more severe than other gastroenteritis episodes. Similar to the data recently reported by Coffin et al (21) in the United States, we also have observed that RV+ patients were more likely to have a combination of diarrhea, vomiting and fever when compared with RV- gastroenteritis cases. These results support that gastroenteritis caused by RV is more severe when compared with other causes.

The impact of RV gastroenteritis beyond direct health care costs has not received extensive attention. Our results show that RV gastroenteritis has an impact on majority of families by causing parental work loss. Similar results have been observed by Jacobs et al (48), who demonstrated that work loss increases with the level of health care sought. Interestingly, we observed that work loss is frequent even in families for whom one parent is unemployed or on parental leave. In the present study, the parents of patients with RV gastroenteritis were more likely to miss days from work and had longer time off work than parents of patients with non-RV-related gastroenteritis. These results demonstrate that RV gastroenteritis has an impact that extends beyond direct health care.

The information collected about other gastroenteritis episodes in the household cannot establish whether RV transmission actually occurred between family members. Nonetheless, our results suggest that transmission of infection may represent an additional source of burden to the families. We reported additional gastroenteritis cases in $46.8 \%$ of households of RV+ children. These findings are in concordance with those reported by Ford-Jones et al (43).

Potential limitations of the present study include ascertainment bias that is present in any study using selfadministered questionnaires for the description of clinical signs and symptoms. In the present study, however, recall bias, although not totally eliminated, is likely low given the short duration of time elapsed between the time of symptom onset and administration of the baseline questionnaire. During the two-week follow-up period of the study, caregivers were asked to report the presence of symptoms, including fever, on a daily basis. However, the accuracy of the reported presence of symptoms before the follow-up period and, in particular, fever, could not be ascertained. Second, the proportion of eligible children who were actually recruited was unknown. Therefore, the results of the present study could not be used to infer the incidence of RV gastroenteritis. Third, by recruiting gastroenteritis cases presenting to community medical practices, the present study adds to the knowledge and understanding from previous studies that were based on hospitalized cases, but it is likely that the cases enrolled in the present study were more severe than gastroenteritis patients treated at home who were not seeking medical care. Therefore, our results may not be representative of the overall pool of community-acquired RV gastroenteritis.

Our study has three main strengths. First, we followed a large sample of children presenting with gastroenteritis in various community medical practices. Second, we longitudinally assessed symptoms, work loss and health care resource utilization over the entire gastroenteritis episode. Previous studies $(21,44)$ examining gastroenteritis in outpatient settings have reported $\mathrm{RV}$-associated symptoms measured at one time point, usually at the time of health care use. In the present study, we describe gastroenteritis symptoms with seven days of retrospective information and two weeks of prospective data collected through symptom diary cards. Through prospective follow-up, we captured the reduction of symptoms over time, in addition to the peak symptom prevalence. Furthermore, prospective follow-up of patients enabled us to assess the duration of gastroenteritis episodes, examine the presence of simultaneous symptoms and capture symptoms that began after the baseline physician consultation. Third, we included children whose symptom onset began up to seven days before presentation at the physicians' offices. For $36.4 \%$ of our study sample, gastroenteritis symptoms began four to seven days before presentation, making our study population more representative of gastroenteritis cases seen in community medical practice compared with studies that used a more strict 
inclusion time frame, such as the $72 \mathrm{~h}$ window used by Coffin et al (21).

Clinical trials have shown RV vaccines to be safe and effective at preventing RV gastroenteritis $(13,16)$. Immunization of newborns against RV infections has the potential to prevent gastroenteritis episodes, which we have found to be clinically more severe and to have greater economic consequences for health care providers and families than other types of gastroenteritis.

ACKNOWLEDGEMENTS: The authors thank the study recruiters for their participation - Dr Darryl J Ableman, Dr Lauri Alto, Dr Geeta Achyuthan, Dr Stephen R Baker, Dr Rebecca Bodok-Nutzati, Dr Terence Brennan, Dr Walter Chang, Dr Walter Chow, Dr Mary Chu, Dr Jasmine Cohen, Dr Katy Driver, Dr Morency Duchastel, Dr Julius Erdstein, Dr Julie Fabbro, Dr Raphael Folman, Dr Yee Tsang Fung, Dr Lee Ann Gallant, Dr Marvin Gans, Dr Hartley Garfield, Dr Norman Goldberg, Dr Saul Greenberg, Dr Stephen Grodinsky, Dr Georges Haddad, Dr Diane Hawthorne, Dr Mabel Hsin, Dr Faeza Jhaveri, Dr Shawn Kao, Dr Alkarim Karmali, Dr Kai Kok Lai, Dr Christian Leduc, Dr Odile Kowalski, Dr Carla Krochak, Dr Louis Lo, Dr Peter
Manson, Dr Alison McCallum, Dr Janette Milne, Dr Patricia Morris, Dr Steven M Moss, Dr Rasik Morzaria, Dr Dokisom Nchama, Dr Ginette Normandin-Noël, Dr Santosh Paikatt, Dr Robert Poupart, Dr William Quan, Dr Jean Ross, Dr Celine Roy-Fleising, Dr Shagufta Shaikh, Dr B Takhar, Dr Quoc Tan Tran, Dr Stephen Treherne, Dr Andy Tsang, Dr Tommy Tung, Dr Vashti Tupper, Dr Pierre Urbanski, Dr Peter Wong, Dr Richard Wong, Dr Kwang Yang, Dr John Yaremko and Dr Michael Zajner.

POTENTIAL CONFLICTS OF INTEREST: JSS Medical Research (Canada) was hired by Merck Frosst Canada Ltd to conduct the present study and perform the data analysis. Dr John S Sampalis is an employee of JSS Medical Research, and Martin Sénécal and Dr James A Mansi are employees of Merck Frosst Canada Ltd. Dr Marc Brisson was an employee of Merck Frosst Canada Ltd during the analysis and write-up of the first draft of the paper. Dr Marc H Lebel and Dr John Yaremko were members of the Advisory Board on vaccines for Merck Frosst Canada Ltd. There are no potential conflicts of interest to report for Dr Richard Wong, Dr Lee Ann Gallant, Dr Hartley A Garfield, Dr Darryl J Ableman and Dr Richard L Ward.

\section{REFERENCES}

1. Parashar UD, Hummelman EG, Bresee JS, Miller MA, Glass RI. Global illness and deaths caused by rotavirus disease in children. Emerg Infect Dis 2003;9:565-72.

2. Clark B, McKendrick M. A review of viral gastroenteritis. Curr Opin Infect Dis 2004;17:461-9.

3. Fruhwirth M, Heininger U, Ehlken B, et al. International variation in disease burden of rotavirus gastroenteritis in children with community- and nosocomially acquired infection. Pediatr Infect Dis J 2001;20:784-91.

4. Fruhwirth M, Karmaus W, Moll-Schuler I, Brosl S, Mutz I. A prospective evaluation of community acquired gastroenteritis in paediatric practices: Impact and disease burden of rotavirus infection. Arch Dis Child 2001;84:393-7.

5. Leung AK, Kellner JD, Davies HD. Rotavirus gastroenteritis. Adv Ther 2005;22:476-87.

6. Raebel MA, Ou BS. Rotavirus disease and its prevention in infants and children. Pharmacotherapy 1999;19:1279-95.

7. Santos N, Hoshino Y. Global distribution of rotavirus serotypes/genotypes and its implication for the development and implementation of an effective rotavirus vaccine. Rev Med Virol 2005;15:29-56.

8. Ford-Jones EL, Mindorff CM, Gold R, Petric M. The incidence of viral-associated diarrhea after admission to a pediatric hospital. Am J Epidemiol 1990;131:711-8.

9. Staat MA, Azimi PH, Berke T, et al. Clinical presentations of rotavirus infection among hospitalized children. Pediatr Infect Dis J 2002;21:221-7.

10. Clark H, Offit P. Vaccines for rotavirus gastroenteritis universally needed for infants. Pediatr Ann 2004;33:536-43.

11. Franco MA, Angel J, Greenberg HB. Immunity and correlates of protection for rotavirus vaccines. Vaccine 2006;24:2718-31.

12. Girard MP, Steele D, Chaignat CL, Kieny MP. A review of vaccine research and development: Human enteric infections. Vaccine 2006;24:2732-50.

13. Ruiz-Palacios GM, Perez-Schael I, Velazquez FR, et al. Safety and efficacy of an attenuated vaccine against severe rotavirus gastroenteritis. N Engl J Med 2006;354:11-22.

14. Van Damme P, Van der Wielen M, Ansaldi F, et al. Rotavirus vaccines: Considerations for successful implementation in Europe. Lancet Infect Dis 2006;6:805-12.

15. Van Damme P, Giaquinto C, Maxwell M, Todd P, Van der Wielen M. Distribution of rotavirus genotypes in Europe, 2004-2005: The REVEAL Study. J Infect Dis 2007;195(Suppl 1):S17-25.

16. Vesikari T, Matson DO, Dennehy P, et al. Safety and efficacy of a pentavalent human-bovine (WC3) reassortant rotavirus vaccine. N Engl J Med 2006;354:23-33.
17. World Health Organization. State of the art of new vaccines research \& development: Initiative for vaccine research. Geneva, Switzerland: World Health Organization, 2003.

18. Bresee JS, Glass RI, Ivanoff B, Gentsch JR. Current status and future priorities for rotavirus vaccine development, evaluation and implementation in developing countries. Vaccine 1999;17:2207-22.

19. Velazquez FR, Matson DO, Calva JJ, et al. Rotavirus infections in infants as protection against subsequent infections. N Engl J Med 1996;335:1022-8.

20. Chang HG, Glass RI, Smith PF, Cicirello HG, Holman RC, Morse DL. Disease burden and risk factors for hospitalizations associated with rotavirus infection among children in New York State, 1989 through 2000. Pediatr Infect Dis J 2003;22:808-14.

21. Coffin SE, Elser J, Marchant C, et al. Impact of acute rotavirus gastroenteritis on pediatric outpatient practices in the United States. Pediatr Infect Dis J 2006;25:584-9.

22. Fischer TK, Viboud C, Parashar U, et al. Hospitalizations and deaths from diarrhea and rotavirus among children $<5$ years of age in the United States, 1993-2003. J Infect Dis 2007;195:1117-25.

23. The Pediatric ROTavirus European CommitTee (PROTECT). The paediatric burden of rotavirus disease in Europe. Epidemiol Infect 2006;134:908-16.

24. Cascio A, Vizzi E, Alaimo C, Arista S. Rotavirus gastroenteritis in Italian children: Can severity of symptoms be related to the infecting virus? Clin Infect Dis 2001;32:1126-32.

25. Fischer TK. Incidence of hospitalizations due to rotavirus gastroenteritis in Denmark. Acta Paediatr 2001;90:1073-5.

26. Giaquinto C, Van Damme P, Huet F, et al. Clinical consequences of rotavirus acute gastroenteritis in Europe, 2004-2005: The REVEAL study. J Infect Dis 2007;195(Suppl 1):S26-35.

27. Giaquinto C, Van Damme P, Huet F, Gothefors L, Van der Wielen M. Costs of community-acquired pediatric rotavirus gastroenteritis in 7 European countries: The REVEAL Study. J Infect Dis 2007;195(Suppl 1):S36-44.

28. Gil A, Carrasco P, Jimenez R, San-Martin M, Oyaguez I, Gonzalez A. Burden of hospitalizations attributable to rotavirus infection in children in Spain, period 1999-2000. Vaccine 2004;22:2221-5.

29. Gleizes O, Desselberger U, Tatochenko V, et al. Nosocomial rotavirus infection in European countries: A review of the epidemiology, severity and economic burden of hospital-acquired rotavirus disease. Pediatr Infect Dis J 2006;25:S12-21.

30. Soriano-Gabarro M, Mrukowicz J, Vesikari T, Verstraeten T. Burden of rotavirus disease in European Union countries. Pediatr Infect Dis J 2006;25:S7-11.

31. Lynch M, O'Halloran F, Whyte D, Fanning S, Cryan B, Glass RI. Rotavirus in Ireland: National estimates of disease burden, 1997 to 1998. Pediatr Infect Dis J 2001;20:693-8. 


\section{Sénécal et al}

32. Matson DO. On a multinational assessment of rotavirus disease in europe. J Infect Dis 2007;195(Suppl 1):S1-3.

33. Chen KT, Chen PY, Tang RB, et al. Sentinel hospital surveillance for rotavirus diarrhea in Taiwan, 2001-2003. J Infect Dis 2005;192(Suppl 1):S44-8.

34. Fischer TK, Anh DD, Antil L, et al. Health care costs of diarrheal disease and estimates of the cost-effectiveness of rotavirus vaccination in Vietnam. J Infect Dis 2005;192:1720-6.

35. Hsu VP, Abdul Rahman HB, Wong SL, et al. Estimates of the burden of rotavirus disease in Malaysia. J Infect Dis 2005;192(Suppl 1):S80-6.

36. Jiraphongsa C, Bresee JS, Pongsuwanna Y, et al. Epidemiology and burden of rotavirus diarrhea in Thailand: Results of sentinel surveillance. J Infect Dis 2005;192(Suppl 1):S87-93.

37. Nakagomi T, Nakagomi O, Takahashi Y, Enoki M, Suzuki T, Kilgore PE. Incidence and burden of rotavirus gastroenteritis in Japan, as estimated from a prospective sentinel hospital study. J Infect Dis 2005;192(Suppl 1):S106-10.

38. Nelson EA, Tam JS, Bresee JS, et al. Estimates of rotavirus disease burden in Hong Kong: Hospital-based surveillance. J Infect Dis 2005;192(Suppl 1):S71-9

39. Nelson EA, Tam IS, Yu LM, et al. Hospital-based study of the economic burden associated with rotavirus diarrhea in Hong Kong. J Infect Dis 2005;192(Suppl 1):S64-70.

40. Nguyen VM, Nguyen VT, Huynh PL, et al. The epidemiology and disease burden of rotavirus in Vietnam: Sentinel surveillance at 6 hospitals. J Infect Dis 2001;183:1707-12.

41. Van Man N, Luan IT, Trach DD, et al. Epidemiological profile and burden of rotavirus diarrhea in Vietnam: 5 years of sentinel hospital surveillance, 1998-2003. J Infect Dis 2005;192(Suppl 1):S127-32
42. Wang XY, Xu ZY, Von Seidlein L, et al. Incidence of diarrhea caused by rotavirus infections in rural Zhengding, China: Prospective, population-based surveillance. J Infect Dis 2005;192(Suppl 1):S100-5.

43. Ford-Jones EL, Wang E, Petric M, Corey P, Moineddin R, Fearon M. Hospitalization for community-acquired, rotavirus-associated diarrhea: A prospective, longitudinal, population-based study during the seasonal outbreak. The Greater Toronto Area/Peel Region PRESI Study Group. Pediatric Rotavirus Epidemiology Study for Immunization. Arch Pediatr Adolesc Med 2000;154:578-85.

44. Ford-Jones EL, Wang E, Petric M, Corey P, Moineddin R, Fearon M. Rotavirus-associated diarrhea in outpatient settings and child care centers. The Greater Toronto Area/Peel Region PRESI Study Group. Pediatric Rotavirus Epidemiology Study for Immunization. Arch Pediatr Adolesc Med 2000;154:586-93.

45. Rivest P, Proulx M, Lonergan G, Lebel MH, Bedard L. Hospitalisations for gastroenteritis: The role of rotavirus. Vaccine 2004;22:2013-7.

46. Ward RL, Bernstein DI, Young EC, Sherwood JR, Knowlton DR, Schiff GM. Human rotavirus studies in volunteers - determination of infectious dose and serological response to infection. Infect Dis 1986;154:871-80.

47. Gilchrist MJ, Bretl TS, Moultney K, Knowlton DR, Ward RL. Comparison of seven kits for detection of rotavirus in fecal specimens with a sensitive, specific enzyme immunoassay. Diagn Microbiol Infect Dis 1987;8:221-8

48. Jacobs P, Shane LG, Fassbender K, Wang EL, Moineddin R, Ford-Jones EL. Economic analysis of rotavirus-associated diarrhea in the metropolitan Toronto and Peel regions of Ontario. Can J Infect Dis 2002;13:167-74. 


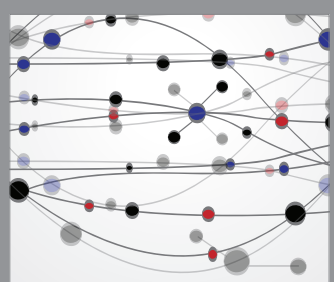

The Scientific World Journal
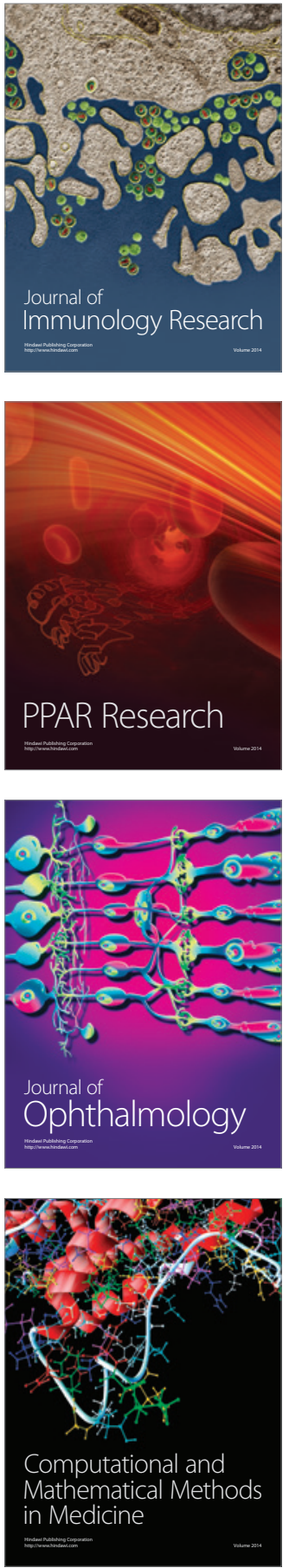

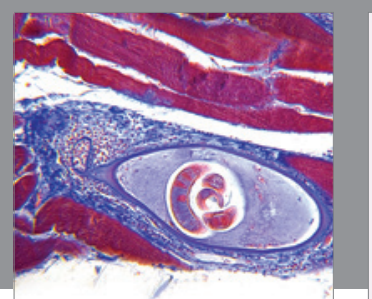

Gastroenterology Research and Practice

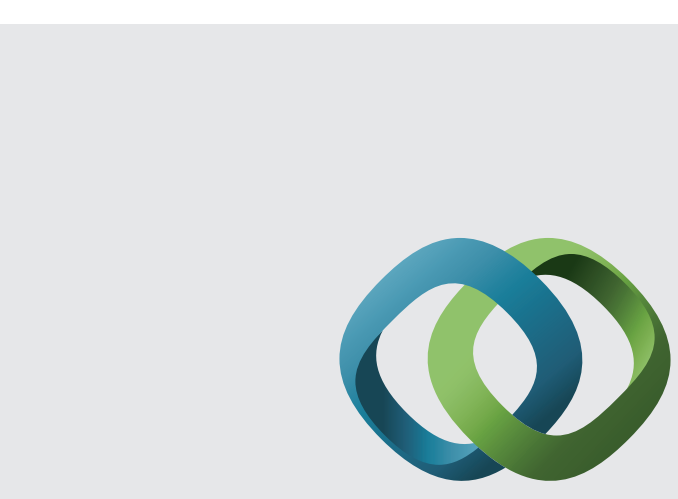

\section{Hindawi}

Submit your manuscripts at

http://www.hindawi.com
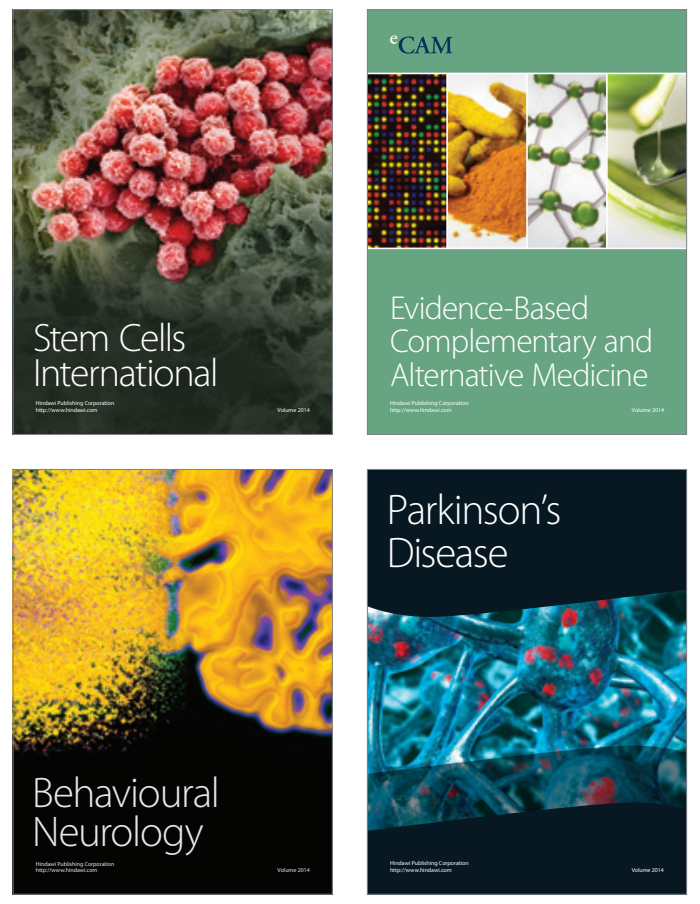
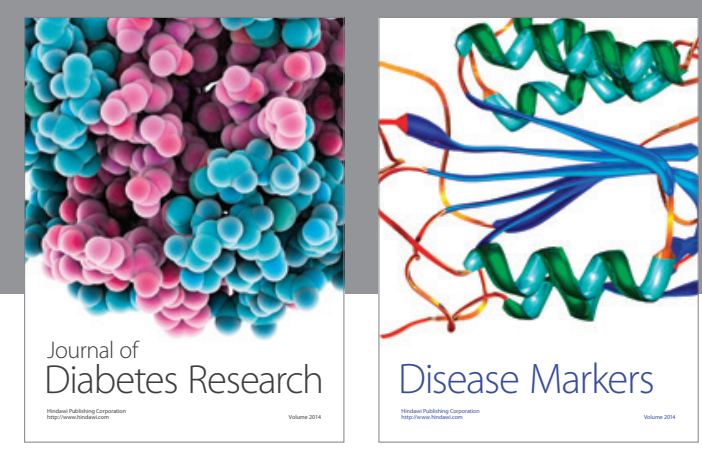

Disease Markers
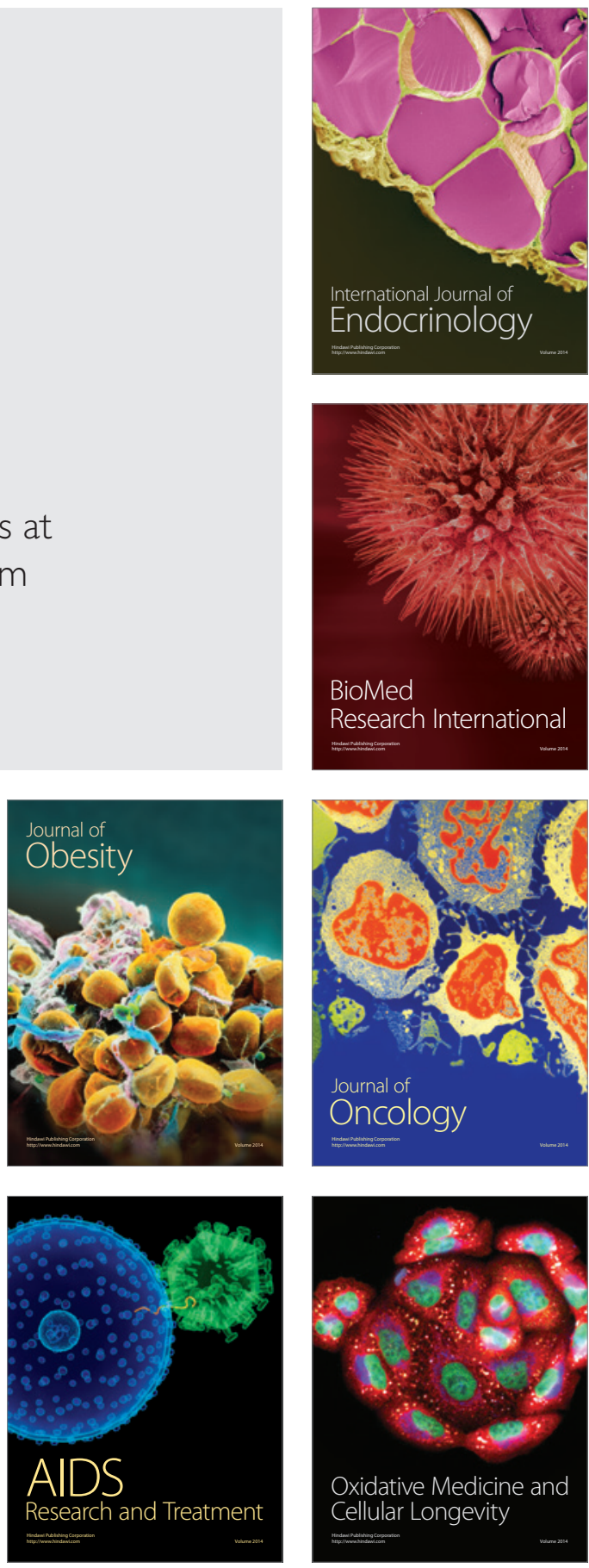